\title{
PEMBERDAYAAN MASYARAKAT MISKIN MELALUI KELOMPOK USAHA BERSAMA (KUBE) DI KECAMATAN BINTAN TIMUR OLEH DINAS SOSIAL KABUPATEN BINTAN
}

\author{
Muhammad Hidayat Nasmi ${ }^{1}$ \\ mhn2895@gmail.com \\ Drs.Karjuni Dt.Maani,M.Si ${ }^{2}$ \\ dtmaani@gmail.com \\ Ilmu Administrasi Negara, Fakultas Ilmu Sosial \\ Universitas Negeri Padang
}

\begin{abstract}
Society empowerment are effort to increase society dignityin the current society. Because so many society can not be free from poverty and backwardness. Social agency of Bintan regency has empowered poor families for helping families in improving social welfare which society empowerment are one of many solution for resolve poverty problem. But in realty still found many problem. The purpose of this research was analyze society empowerment of poor through joint business ( Kube) in sub-district of east bintan by Social agency of Bintan regency. the method used is descriptive with a qualitative approach and using primary and secondary data. Data collection techniques used in this study were interviews, observation, and documentation. The results of the study indicate that the program has not been able to improve the people who are members of the KUBE program. This was apparent in several joint business groups (KUBE) who had difficulties in marketing, because they were not given easy access to the management of halal labels and permits from BPOM. So that society have difficulty entering their products more broadly, because it is a requirement of supermarkets and mini markets and bazaars made by the private sector.
\end{abstract}

keywords: society empowerment, joint business group (KUBE) 


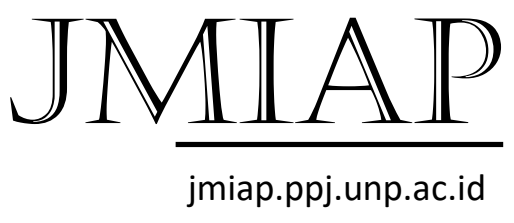

JURNAL ILMU ADMINISTRASI PUBLIK

Email : jianfis.unp@gmail.com

Vol. 2 No. 1 Maret 2019

\section{PENDAHULUAN}

Pemberdayaan masyarakat merupakan upaya untuk meningkatkan harkat dan martabat lapisan masyarakat yang dalam kondisi sekarang tidak mampu untuk melepaskan diri dari perangkap kemiskinanan dan keterbelakangan. Karena dalam pelaksaanaan sitem pengetahuan, sistem poltik, sistem hukum dan ideologi secara sistematik akan menciptakan dua kelompok masyarakat yaitu masyarakat berdaya dan masyarakat tuna berjaya. Proses pemberdayaan menekankan pada proses memberi kemampuan pada masyarakat agar menjadi berdaya, mendorong atau memotivasi individu agar mempunyai kemampuan atau keberdayaan untuk menentukan pilihan hidupnya .

Dengan adanya Undang-undang Republik Indonesia Nomor 11 tahun 2009 tentang kesejahteraan sosial dan Undangundang Republik Indonesia Nomor 13 Tahun 2011 tentang penanganan fakir miskin, hal ini merupakan bentuk kepedulian pemerintah terhadap permasalahan social yang dihadapi oleh masyarakat keluarga fakir miskin disetiap daerah. Salah satu betuk upaya pemerintah yaitu dengan adanya program kelompok usaha bersama (KUBE). Kelompok usaha bersama merupakan kegiatan yang ditunjukan untuk meningkatkan kemampuan dalam mengakses sumber daya ekonomi,produktivitas kerja, kemampuan usaha ekonomi dan menciptakan kemitraan usaha yang saling menguntungkan.

Kelompok usaha bersama yang selanjutnya disingkat KUBE adalah himpunan dari keluarga fakir miskin yang dibentuk tumbuh dan berkembang atas dasar prakasa sendiri, saling berinteraksi antara satu dengan yang lain dan tinggal dalam satu wilayah tertentu dengan tujuan untuk meningkatkan produktivitas anggotanya, meningkatkan relasi sosial yang harmonis, memenuhi kebutuhan anggotanya, memecahkan masalah sosial yang dialami dan menajdi wadah pengembangan usaha bersama. Kelompok Usaha Bersama (KUBE) dijabarkan dalam peraturan Gubernur Provinsi Kepualaun Riau nomor 23 tahun 2010 tentang penyaluran dana bantuan keuangan kepada Kabupaten/Kota untuk pelaksanaan program pengentasan kemiskinan di Provinsi Kepualau Riau. Di dalam program tersebut terdapat sub program yaitu menumbuh kembangkan kelompok usaha bersama (KUBE). Hal itu merupakan wujud kepedulian Pemerintah Provinsi Kepualau Riau dalam mengatasi masalah masyarakat penyandang masalah kesejahteraan sosail (PMKS).

Program Kelompok Usaha Bersama (KUBE) sebagai wujud dari pemberdayaan masyarakat dicetuskan melalui Keputusan Menteri Sosial Nomor 84/HUK/1997 tentang "Pelaksanaan Pemberian Bantuan Sosial Keluarga Fakir Miskin". Program KUBE sebagai Program Kesejahteraan Sosial (PROKESOS) dalam upaya pemberdayaan masyarakat miskin melalui kelompok, mempunyai tujuan yaitu: Pertama, peningkatan kemampuan berusaha para anggota secara bersama dalam kelompok; Kedua, peningkatan pendapatan; Ketiga, pengembangan usaha; dan Keempat, peningkatan kepedulian dan kesetiakawanan sosial di antara para anggota dan dengan masyarakat sekitar. Tujuan akhir Program KUBE adalah menjadi embrio koperasi dan Lembaga Keuangan Mikro (LKM).

Pelaksanaan program kelompok usaha berama (KUBE) telah diatur melalui Peraturan Daerah Kabupaten Bintan Nomor 8 Tahun 2012 yang mengatur tentang implementasi bantuan kelompok usaha bersama (KUBE).Program KUBE diharapkan oleh pemerintah menjadi media untuk meningkatkan motivasi warga miskin agar lebih maju secara ekonomi dan sosial, 


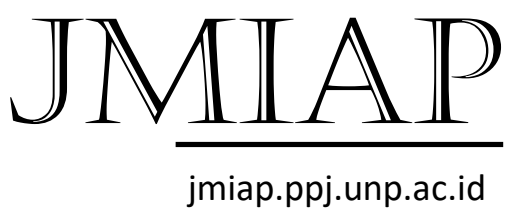

JURNAL ILMU ADMINISTRASI PUBLIK

Email : jianfis.unp@gmail.com

Vol. 2 No. 1 Maret 2019 meningkatkan interaksi dan kerjasama dalam kelompok, mendayagunakan potensi dan sumber sosial ekonomi lokal, memperkuat budaya kewirausahaan, mengembangkan akses pasar, dan menjalin kemitraan sosial ekonomi dengan 8 berbagai pihak terkait.

Namun dalam pemberdayakan masyarakat fakir miskin di Kecamatan Bintan Timur, Dinas Sosial Kabupaten Bintan, masih ditemukan berbagai permasalahan seperti kurangnya motivasi masyarakat. Disisi lain masyarakat dalam pemberdayaan mendapatkan bantuan senilai Rp.20.000.000 per kube namun bantuan itu tidak langsung diberiakn setelah kube itu terbentuk ada beberapa syarat yang harus di penuhi yaitu aktif, administrasi lengkap, dan terdaftar dari BDT dan harus berjalan beberapa tahun sebelum mendapat bantuan biasanya anggota kube mengumpulkan kas.

Penelitian ini bertujuan untuk menganalisis pemberdayaan masyarakat keluarga miskin melalui kelompok usaha bersama (KUBE), mengetahui kendala pemberdayaan masyarakat keluarga miskin melalui kelompok usaha bersama (KUBE) dan untuk mendeskripsikan upaya dalam mengatasi kendala pemberdayaan masyarakat keluarga miskin melalui kelompok usaha bersama (KUBE) di Kecamatan Bintan Timur oleh Dinas Sosial Kabupaten Bintan.

Adapun rumusan masalah dalam penelitian ini adalah:

1. Bagaimana pemberdayaan masyarakat keluarga miskin melalui Kelompok Usaha Bersama (KUBE) di Kecamata Bintan Timur oleh Dinas Sosial Kabupaten Bintan. 2. Apa saja kendala pemeberdayaan masyrakat keluarga fakir miskin melalui Kelompok Usaha Bersama (KUBE) di Kecamatan Bintan Timur Oleh Dinas Sosial Kabupaten Bintan.

\section{TINJAUAN PUSTAKA \\ Pemberdayaan}

Menurut Usman dalam (Mulyono, 2017) pemberdayaan adalah suatu proses pembelajaran masyarakat untuk mengembangkan seluruh potensi agar dapat berperan serta dalam pembangunan.Pemberdayaan bertujuan untuk menemukan alternatif-alternatif dalam pembangunan masyarakat. Dalam konteks ini, proses pemberdayaan dapat di pandang sebagai depowerment dari system kekuasaan yang mutlak-absolut (intelektual,religious,politik, ekonomi dan militer) konsep ini kemudian digantikan oleh landasan baru yang berlandasan ide manusia dan kemanusiaan (humanism). Konsep ini memiliki doktrin yang sama dengan aliran fenomenologi, eksistensialisme dan personalisme yang menolak segala bentuk power yang bermuara hanya pada proses dehumanisme eksistensi manusia.

Demikian juga aliran Neo-Marxis, freudianisme, sosiologi kritik yang menolak industralisasi , kapitalisme dan teknologi. Mereka beralasan bahwa ketiga hal tersebut dapat mematikan manusia dan kemanusiaan.Adapun cita-cita dari aliran ini adalah untuk menemukan sistem yang sepenuhnya berpihak kepada manusia dan kemanusiaan.

Menurut Hikmat dalam (Mulyono, 2017) menyatkan bahwa pemberdayaan menandung dua arti.Pengertian pertama adalah to give power or authority pengertian kedua to give ability to or enable. Pemaknaan pengertian pertama disuatu sisi meliputi memberikan kekuasaan,mengalihkan kekuatan atau mendelegasi otoritas kepada 
pihak yang kurang. Sedangkan pemaknaa yang kedua adalah memberikan peluang kepada pihak lain untuk melakukan suatu usaha.

Berbeda dengan pendapat tersebut Sumodiningrat dalam (Mulyono, 2017) menyampaikan, pemberdayaan sebenarnya merupakan khas Indonesia dari pada barat. Di barat istilah tersebut diterjemahkan sebagai empowerment, istilah itu tidak tepat. Pemberdayaan yang bertujuan memberi "daya" bukanlah "kekuasaaan"

Sedangkan menurut Parson dalam (Suyono, 2014) mengatakan bahwa pemberdayaan menekankan bahwa orang memperoleh keterampilan, pengetahuan dan kekuasaan yang cukup untuk mempengaruhi kehidupannya dan kehidupan orang lain yang menjadi perhatiannya.

Menurut Usman dalam (Mulyono, 2017) pemberdayaan adalah suatu proses pembelajaran masyarakat untuk mengembangkan seluruh potensi agar dapat berperan serta dalam pembangunan.

\section{a. Strategi \\ Pemberdayaan \\ Masyarakat}

Menurut pendapat dari Suharto dalam (Soebianto, 2013) terhadap strategi peemberdayaan masyarakat, ia mengemukakan adanya lima aspek penting yang dapat dilakukan dalam melakukan pemberdayaan masyarakat, khususnya melalui pelatihan dan advokasi terhadap masyarakat miskin, yaitu :

1. Motivasi

dalam hubungan ini setiap keluarga harus, setiap keluarga harus dapat memahami nilai kebersamaan, iteraksi sosial dan kekuasaan melalui pemahaman akan haknya sebagai warna Negara dan anggota masyrakat

2. Peningkatan kesasaran dan pelatihan kemampuan

Peningkat dan kesadaran masyrakat dapat dicapai melalui pendidikan dasar, perbaikan kesehatan, imunisasi dan sanitasi.

3. Manajemen diri

Setiap kelompok masyrakat harus mampu memilih pemimpin mereka sendiri dan mengatur kegiatan mereka sendiri, seperti melaksankan pertemuan-pertemuan, melakukan pencatatan dan pelaporan, mengoperasikan tabungan dan kredit, resolusi konflik dan manajemen kepemilikan masyrakat

4. Mobilisai dalam hal sumberdaya masyarakat, diperlukan beberapa metode dalam menghimpun sumber individu berupa tabungan dan sumbangan sukarela

\section{Kemiskinan \\ Pengertian kemiskinan}

Kemiskinan merupakan fenomena yang masih sulit dipecahkan oleh bangsa Indonesia.Kemiskinan juga memunculkan berbagai masalah seperti kebodohan, pengangguran, kelaparan, kesenjangan sosial, kesehatan.Pada dasarnya kemiskinan adalah masalah yang dihadapi oleh semua Negara di dunia, tidak terkecuali Negara maju seperti amerika serikat.

Menurut Todaro dalam (Mulyono, 2017) menyatakan absolute (absolute poverty) mengacu kepada semua penduduk yang hidup dibawah "garis kemiskinan internasional" atau yang kurang dari pendapatan minimum tertetu.Sedangkan istilah miskin menurut Thoir dalam 


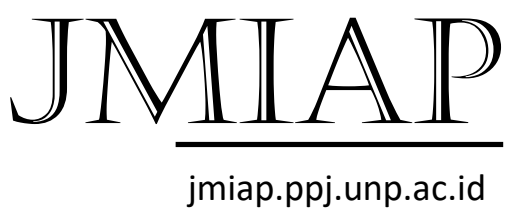

(Mulyono, 2017) adalah kondisi yang secara umum menggambarkan suatu rumah tangga, komunitas, atau sesorang yang berda dalam kekurangan, terutama kaitannya dengan pemenuhan yang paling dasar.

Sedangkan menurut pendapat Ambar dalam (Mulyono, 2017) kemiskinan itu sendiri ditandai oleh kondisi masyarakat yang serba terbatas, baik dalam aksebilitas pada factor produksi, peluang atau kesempatan berusaha, pendidikan, serta fasilitas hidup lainnya sehingga dalam setiap aktivitas maupun usaha menjadi sangat terbatas.

\section{a) Ukuran Kemiskinan}

Menurut Ravallion dalam (Mulyono, 2017) ukuran kemiskinan dipertimbangkan berdasarkan pada norma-norma tertentu.Pilihan nrma tersebut sangat penting terutama dalam hal pengukuran kemiskinan yang didasarkan konsumsi. Garis kemiskinan yang didasarkan konsumsi terdiri dari dua elemen, yaitu (1) pengeluaran untuk membeli standar gizi minimum dan kebutuhan mendasar lainnya (2) jumlah kebutuhan yang sangat bervariasi, yang mencerminkan biaya partisipasi dalam kehidupan masyarakat sehari-hari.

Di Indonesia, Badan Pusat Statistik (2008) biasanya mengeluarkan garis kemiskinan yang disesuaikan dengan wilayah perdesaan dan perkotaan serta Kabupaten/Kota di seluruh Indonesia. Studi penentua criteria penduduk miskin (SPKPM), untuk mengetahui karakteristik rumah tangga yang mampu mencicirkan
Email : jianfis.unp@gmail.com Vol. 2 No. 1 Maret 2019

kemiskinan secara konseptual.Informasi ini berguna untuk penentuan sasaran rumah tangga program pengentasan kemiskinan. Dari hasil SPKM 2000, diperoleh enam variable yag dianggap layan dan oprasioanal untuk penentuan rumah tangga miskin di lapangan. Skor 1 mengacu pada sifat-sifat yang mencirikan kemiskinan dan skor 0 menicrikan ketidak miskinan.

\section{Tabel 1.3 Indikator Rumah Tangga Miskin}

\begin{tabular}{|c|c|}
\hline $\begin{array}{l}\text { 1.luas lantai perkapita } \\
\qquad \quad<=8 \mathrm{~m} \text { (skor 1) } \\
\qquad \quad>=8 \mathrm{~m} \text { (skor 0) } \\
\text { 2. jenis lantai } \\
\bullet \quad \text { Tanah (skor 1) } \\
\bullet \quad \text { Bukan tanah } \\
\quad \text { (skor 0) } \\
\text { 3.Air minum/ketersedian air } \\
\text { bersih } \quad \text { Air hujan/sumur } \\
\text { - } \quad \text { tidak terlindungi } \\
\text { (skor 1) } \\
\text { PAM, sumur } \\
\text { terlindungi (skor } \\
\text { 0) }\end{array}$ & 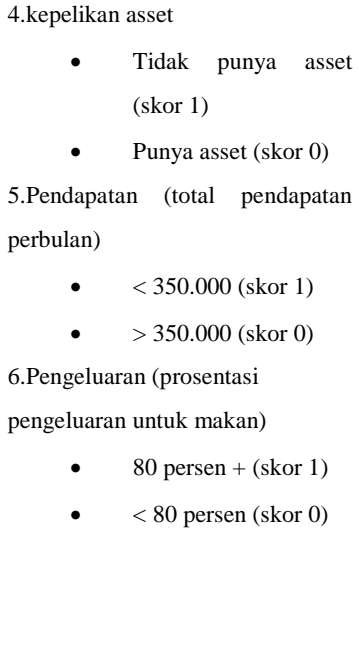 \\
\hline
\end{tabular}

\section{d. Teori Kendala}

(Haksama, 2016) mengungkapkan Teori of constraints merupakan suatu penafsiran penggunaan yang dikembangkan arah dengan Dr. Eliyahu M. Goldratt dari tahun 1980-an. Teori constraints di artikan seperti satu menuju penambahan metode yang bertujuan bagian-bagian yang memisahkan kemampuan dalam kenaikan hasil

(Haksama, mengelompokkanjenis kendala beralaskan dari dan berasalkan bentuknya.

1) Berdasarkan Bentuknya: 


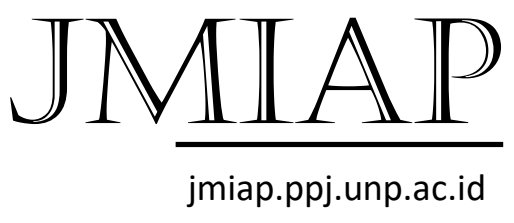

a) Kendala merupakan bagian-bagian yang menetapkan industri maupun kelompok dan struktur yang bermula di dalam industri.

b) Kendala merupakan bagian-bagian yang membatasi industry yang berawal dari eksternal industriatau dapat disimpulkan dari luar kelompok maupun sistem

\section{METODE PENELITIAN}

penelitian ini memakai jenis penelitian kualitatif memakai metode deskriptif. Penelitian dilakukan di Penelitian yang dilakukan di Kecamatan Bintan Timur, yaitu di Kecamatan Bintan Timur Kabupaten Bintan. Pemilihan informan dalam penelitian ini menggunakan teknik purposive sampling. Penggunaan sistem Purposive Sampling dalam penelitian ini supaya peneliti mendapatkan data yang valid dan maksimal. Data yang digunakan dalam penelitian ini adalah data primer dan data sekunder. Data primer diperoleh melalui wawancara dan observasi langsung dari informan. Data sekunder diperoleh melalui studi dokumentasi terhadap literatur yang dapat menunjang penelitian.

Agar memperoleh hasil kredibilitas yang sangat baik maka dari itu di dalam penelitian ini menggunakan bentuk pengkajian kesahan informasi yang sesuai atas pendapat (Moleong, 2006) yaitu teknik triangulasi sumber yang dilakukan dengan cara melakukan member check sampai dicapai tahap kejenuhan data. Proses analisis data dimulai dengan pengumpulan data, reduksi data, penyajian data, dan terakhir penarikan kesimpulan.

HASIL DAN PEMBAHASAN

a. Pemberdayaan Masyarakat Miskin Melalui Kelompok Usaha Bersama (KUBE) Di Kecamatan Bintan Timur Oleh Dinas Sosial Kabupaten Bintan
JURNAL ILMU ADMINISTRASI PUBLIK

Email : jianfis.unp@gmail.com

Vol. 2 No. 1 Maret 2019

Menurut Usman dalam (Mulyono, 2017) pemberdayaan adalah suatu proses pembelajaran masyarakat untuk mengembangkan seluruh potensi agar dapat berperan serta dalam pembangunan. Pemberdayaan bertujuan untuk menemukan alternatif-alternatif dalam pembangunan masyarakat. Menurut Hikmat dalam (Mulyono, 2017) menyatakan bahwa pemberdayaan mengandung dua arti.Pengertian pertama adalah to give power or authority. pengertian kedua to give ability to or enable. Pemaknaan pengertian pertama disuatu sisi meliputi memberikan kekuasaan, mengalihkan kekuatan atau mendelegasi otoritas kepada pihak yang kurang. Sedangkan pemaknaan yang kedua adalah memberikan peluang kepada pihak lain untuk melakukan suatu usaha.

Analisa Pemberdayaan masyarakat fakir miskin melalui kelompok usaha bersama (KUBE) di Kecamatan Bintan Timur oleh Dinas Sosial Kabupaten Bintan dapat dilihat dengan beberapa indicator yaitu, (a) Motivasi, (b) Pelatihan, dan (c) Modal.

\section{Motivasi}

Dalam hubungan ini, setiap keluarga harus dapat memahami nilai kebersamaan, iteraksi sosial dan kekuasaan melalui pemahaman akan haknya sebagai warna Negara dan anggota masyarakat.Karena itu, setiap rumah tangga perlu didorong untuk membentuk kelompok yang merupakan mekanisme kelembagaan penting untuk mengorganisir dan melaksanakan kegiatan pengembangan masyarakat di desa.Kelompok ini kemudian dimotivasi untuk terlibat dalam kegiatan peningkatan pendapatan dengan menggunakan sumbersumber dan kemampuan-kemampuan mereka sendiri.

Dalam Pemberdayaan masyarakat fakir miskin melalui kelompok usaha 


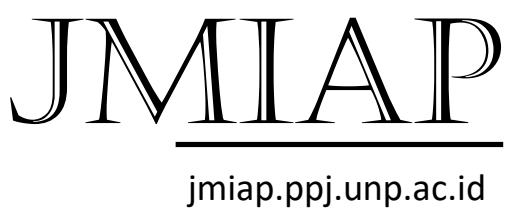

JURNAL ILMU ADMINISTRASI PUBLIK

Email : jianfis.unp@gmail.com

Vol. 2 No. 1 Maret 2019

bersama (KUBE) di Kecamatan Bintan Timur oleh Dinas Sosial Kabupaten Bintan sudah melakukan motivasi dengan baik, sehingga masyarakat dalam hal ini yang akan menjadi bagian terpenting dalam menyukseskan program KUBE tersebut sangat terdorong untuk bangkit dan berani membentuk kelompok usaha yang dalam pelaksanaannya dibantu oleh Pemerintah. Keban dalam (Mulyono, 2017) menjelaskan tujuan yang ingin dicapai dari pemberdayaan adalah membentuk individu dan masyarakat menjadi mandiri. Kemandirian tersebut meliputi kemandirian berfisik, bertindak, dan mengandalkan apa yang mereka lakukan tersebut. Beracuan pada tujuan Pemberdayaan yang dijelaskan oleh Keban, sangat jelas dapat dipahami bahwa tujuan utama dari pemberdayaan adalah melahirkan kemandirian dari masyarakat.Agar kemandirian tersebut bisa dicapai, maka Pemerintah memiliki peran penting dalam mewujudkannya.Lahirnya program KUBE ini merupakan langkah tepat yang dilakukan Pemerintah untuk menjalankan tanggungjawabnya dalam mewujudkan kemandirian pada masyarakat fakir miskin.

Untuk mewujudkan Kemandirian yang merupakan tujuan dari Pemberdayaan, Dinas Sosial Kabupaten Bintan yang merupakan lembaga bertanggungjawab terhadap berjalannya pemberdayaan masyarakat fakir miskin di Kabupaten Bintan melalui Program Kelompok Usaha Bersama (KUBE) ini sudah melakukan Pemberdayaan yang dimulai dengan pemberian motivasi kepada masyarakat fakir miskin yang akan menjadi bagian dari terselenggaranya program ini. Motivasi kepada masyarakat dilakukan dengan mendatangkan Motivator dari Pusat yang mempunyai kemampuan motivasi yang baik untuk mendorong masyarakat menjadi berani melakukan usaha dan siap keluar dari keterpurukan.
Motivasi yang dilakukan oleh Dinas Sosial Kabupaten Bintan merupakan langkah awal dalam menggerakkan masyarakat untuk berani melakukan usaha dengan bantuan program Kelompok Usaha Bersama (KUBE). Upaya yang dilakukan oleh Dinas Sosial Kabupaten Bintan sejauh ini dinilai oleh masyarakat yang sudah menjadi bagian dari program tersebut sudah terlaksana dengan baik dan sangat membantu untuk masyarakat berani memulai membentuk usaha dalam bentuk Kelompok Usaha Bersama (KUBE).

\section{Pelatihan}

Peningkat dan kesadaran masyrakat dapat dicapai melalui pendidikan dasar, perbaikan kesehatan,imunisasi dan sanitasi.Sedangkan keterampilanketerampilan vokasional bisa dikembangkan melalui cara-cara partisipatif.Pengetahuan local yang biasanya diperoleh melalui pengalaman dapat dikombinasikan dengan pengetahuan dari luar.Pelatihan semacam ini dapat membantu masyarakat miskin untuk menciptakan mata pencaharian sendiri atau membantu meningkatkan keahlian mereka untuk mencari pekerjaan di luar wilayahnya.

Pelatihan menjadi bagian yang sangat penting dalam memberikan pengetahuan dan membentuk keterampilan bagi setiap masyarakat yang akan menjadi bagian dari program Kelompok Usaha Bersama (KUBE). Pelatihan yang diberikan kepada masyarakat sangat membantu untuk membentuk keterampilan bagi masyarakat, agar pemberdayaan yang dilakukan oleh Dinas Sosial Kabupaten Bintan sesuai dengan rencana dan tujuan dari program tersebut.

Mulyono dalam (Mulyono, 2017) menjelaskan karakteristik orang miskin, salah satunya adalah seseorang yang memilki kemauan, tetapi tidak memilki 


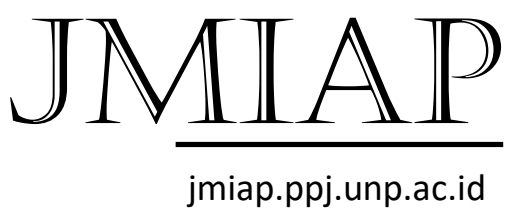

JURNAL ILMU ADMINISTRASI PUBLIK

Email : jianfis.unp@gmail.com

Vol. 2 No. 1 Maret 2019

kemampuan, seseorang ini memilki kemauan untuk melakukan kegiatan dalam menunjang kehidupan, tetapi tidak memilki kemampuan atau keterampilan oleh pasar baik di bidang industry maupun di bidang usaha. Sebagaimana yang dijelaskan oleh Mulyono tersebut sesuai dengan kondisi masyarakat setelah diberikan motivasi oleh Dinas Sosial Kabupaten Bintan.Dimana masyarakat telah diberikan dorongan yang melahirkan keinginan dan kemauan melakukan usaha.Kemauan yang besar dari masyarakat tersebut perlu disertai dengan kemampuan dan keterampilan melakukan usaha.

Dinas Sosial Kabupaten Bintan dalam menyukseskan Program Pemberdayaan Kelompok Usaha Bersama (KUBE) telah mampu melahirkan kemauan dalam diri masyarakat fakir miskin untuk menjalankan usaha.Setelah melakukan motivasi untuk mendorong masyarakat Dinas Sosial Kabupaten Bintan selanjutnya melakukan Pelatihan untuk memberikan pemahaman dan memberikan keterampilan kepada masyarakat.Pelatihan tersebut dilakukan berdasarkan kebutuhan dari KUBE yang telah dibentuk oleh masing-masing masyarakat, baik itu pelatihan KUBE yang ingin bergerak dalam kerajinan tangan, kuliner, dan sebagainya. Pelatihan yang dilakukan oleh Dinas Sosial Kabupaten Bintan dalam pelaksanaan Pemberdayaan Kelompok Usaha Bersama tersebut sejauh ini belum mampu memberikan keterampilan secara menyeluruh kepada seluruh anggota Kelompok Usaha Bersama yang tergabung. Masih terdapat anggota KUBE yang tidak begitu mahir dalam menjalankan tugasnya sebagai anggota dari kelompok usaha.Selain itu, Pelatihan yang dilakukan tidak menyentuh secara spesifik untuk pemasaran produk yang dihasilkan.Hal itu dirasakaan oleh beberapa KUBE yang peneliti temui di lapangan.
Pelatihan yang hanya melibatkan Ketua dan sekretaris KUBE yang berarti Ketua dan sekretaris itulah yang bertanggungjawab untuk memberikan pemahaman kepada anggota mereka masing-masing.Hal itu dinilai menjadi salah satu faktor tidak semua anggota KUBE mahir dalam menjalankan tugas mereka di dalam kelompok tersebut.Titik lemah dalam pelaksanaan pemberdayaan tersebut harus dilakukan perbaikan oleh Dinas Sosial agar upaya mewujudkan kemandirian terhadap masyarakat fakir miskin dapat terlaksana sebagaimana mestinya.

\section{Modal}

Untuk mobilisasi sumberdaya masyarakat, diperlukan metode untuk menghimpun sumber-sumber individu melalui tabungan regular dan sumbangan sukarela dengan tujuan penciptakan modal sosial.Ide ini didasari pandangan bahwa setiap orang memiliki sumbernya sendiri yang jika dikumpulkan, dapat meningkatkan kehidupan sosial ekonomi secara substansial.

Dalam melakukan usaha di bidang apapun, Modal menjadi bagian sangat penting agar usaha tersebut bisa berjlaan dengan baik. Modal yang diterima oleh Kelompok Usaha Bersama (KUBE) di Kabupaten Bintan didapatkan dari Pemerintah setelah Basis Data Terpadu (BDT) yang menjadi syarat agar kelompok tersebut mendapatkan bantuan dana dari Pemerintah. Setelah terdaftar di BDT yang merupakan data terpusat di Kementerian Sosial, Pemerintah Daerah melalui Dinas Sosial akan melakukan Motivasi dan pelatihan terhadap KUBE yang sudah terdaftar. Setelah melewati tahapan tersebut, maka KUBE yang terdaftar akan diberikan bantuan modal usaha oleh Pemerintah. Modal dari Pemerintah inilah yang menjadi penggerak bagi masyarakat yang tergabung dalam 


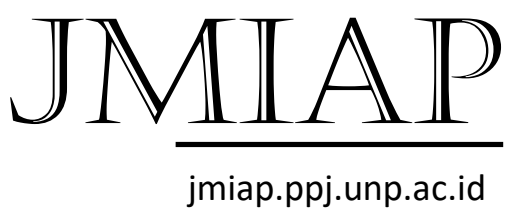

JURNAL ILMU ADMINISTRASI PUBLIK

Email : jianfis.unp@gmail.com

Vol. 2 No. 1 Maret 2019

Kelompok Usaha Bersama.Melalui modal yang diberikan Pemerintah yang diolah oleh masyarakat dalam bentuk usaha bersama.

\section{Kendala Dalam Pemberdayaan Masyarakat Keluarga Miskin Melalui Kelompok Usaha Bersama (KUBE) di Kecamatan Bintan Timur oleh Dinas Sosial Kabupaten Bintan}

Dalam Pemberdayaan Masyarakat Keluarga Miskin Melalui Kelompok Usaha Bersama (KUBE) di Kecamatan Bintan Timur oleh Dinas Sosial Kabupaten Bintan, terdapat berbagai macam kendala yang dihadapi baik oleh Dinas Sosial Kabupaten Bintan sebagai Instansi yang bertanggung jawab, maupun masyarakat yang tergabung dalam Kelompok Usaha Bersama (KUBE). Sebagaimana yang dijeaskan oleh Hansen dan Mowen dalam (Haksama, 2016) mengelompokkan jenis kendala yang berawal dari asalnya, yaitu Kendala Internal dan Kendala Internal

\section{a. Kendala Internal}

Kendala Internal (Internal constraint) merupkan bagian-bagian mengelompokan industri maupun kelompok berawal dari sebuah industry ataupun organisasi. Dalam setiap program tentunya terdapat kendalakendala yang dialami oleh setiap unsur yang terlibat dalam program tersebut.Begitupun dengan Pemberdayaan Mayarakat melalui Program Kelompok Usaha Bersama (KUBE) di Kabupaten Bintan.Dari data yang peneliti temui di lapangan diketahui terdapat beberapa kendala yang dialami secara internal, baik oleh Instansi terkait yaitu Dinas Sosial Kabupaten Bintan, mapun masyarakat yang tergabung dalam Kelompok Usaha Bersama (KUBE).

Secara Internal Dinas Sosial Kabupaten Bintan mengalami kendala yang menjadi hambatan dalam menyukseskan program KUBE tersebut, kendala yang dialami adalah kurangnya Sumber Daya Manusia yang tersedia di Dinas Sosial Kabupaten Bintan. Dimana SDM yang tersedia tidak mencukupi untuk mampu mengkoordinir Kelompok-kelompok yang sudah terbentuk secara maksimal, sehingga timbul keluhan dari beberapa KUBE yang merasa tidak diperhatikan, walaupun Dinas Sosial kabupaten Bintan sudah berupaya semaksimal mungkin, tetap saja kekurangan jumlah SDM yang tersedia menjadi hambatan dalam komunikasi dengan Kelompok-kelompok yang sudah terbentuk. Selain Dinas Sosial Kabupaten Bintan, masyarakat yang merupakan subjek penting dalam Pemberdayaan ini juga memiliki kendala-kendala secara internal. Hal itu terlihat dari pengakuan beberapa KUBE yang mengatakan bahwa cukup sulit mereka dalam menyesuaikan waktu satu sama lain. Beracuan pada prinsip pemberdayaan yang dijelaskan Mardikanto dalam (Nurwati, 2008) salah satu dari prinsip tersebut adalah harus adanya prinsip kedisiplinan, keseriusan, serta profesioal di kalangan yang terlibat. Jika melihat temuan peneliti di lapangan, lalu dihubungkan dengan prinsip pemberdayaan yang disampaikan Mardikanto jelas terdapat prinsip penting dalam Pemberdayaan yang masih menjadi pertanyaan dalam penerapan program Pemberdayaan masyarakat kabupaten Bintan melalui program KUBE.

Kedisiplinan, keseriusan, serta professional merupakan prinsip yang seharusnya dipegang oleh semua unsure yang terlibat.Baik itu DInas Sosial Kabupaten Bintan, apalagi masyarakat yang tergabung dalam Kelompok Usaha Bersama (KUBE) tersebut.Untuk mewujudkan profesionalitas dari Dinas Sosial tentunya penambahan Sumber Daya Manusia menjadi keharusan agar upaya menyukseskan program ini tidak menjadi sia-sia.Dalam keberlangsungan Pemberdayaan ini, Pemerintah melalui 


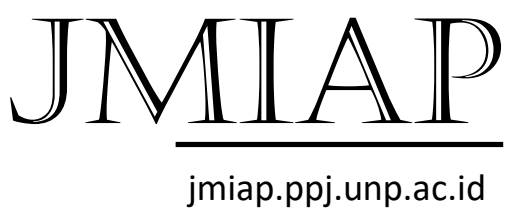

JURNAL ILMU ADMINISTRASI PUBLIK

Email : jianfis.unp@gmail.com

Vol. 2 No. 1 Maret 2019

DInas Sosial juga harus mampu memperhatikan keseriusan, kedisiplinan, serta profesionalitas dari setiap anggota KUBE yang tergabung. Sejauh ini kendala yang dialami cukup mempengaruhi pemberdayaan itu sendiri.

\section{b. Kendala Eksternal}

Kendala ini bertujuan untuk mebagibagi industri dan kelompok berawal dari luar..Dalam pelaksanaan Program Pemberdayaan melalui Program Kelompok Usaha Bersama (KUBE) Kabupaten Bintan terdapat kendala eksternal yang menghambat berjalannya pemberdayaan tersebut.

Kendala eksternal utama yang dialami adalah masyarakat yang tergabung dalam KUBE tersebut kesulitan dalam pemasaran produk hasil usaha mereka.Karena sebagian besar KUBE bergerak dalam usaha makanan atau kuliner, sehingga untuk memasukkan produk ke supermarket harus terlebih dahulu memenuhi syarat dari BPOM serta mendapatkan label halal. Dinas Sosial sudah berupaya berkoordinasi dengan Dinas lain yang terkait, namun belum terdapat perkembangan yang berarti untuk kendala tersebut.

Kesulitan yang dialami oleh masyarakat untuk mendapat label halal serta mendapat izin BPOM membuat pemasaran yang dilakukan hanya kepada warung-warung kecil yang terdapat di kabupaten Bintan. Hal itu mengakibatkan proses pemasaran produk usaha mereka tidak berjalan dengan begitu baik serta kurang maksimal. Pemsaran menjadi hal yang sangat penting dalam dunia usaha, maka dari itu kendala ini menjadi hambatan yang sangat berarti untuk masyarakat yang tergabung dalam program tersebut.

\section{b. Upaya untuk mengatasi kendala Pemberdayaan Masyarakat Keluarga Miskin Melalui Kelompok Usaha}

\section{Bersama (KUBE) di Kecamatan Bintan Timur oleh Dinas Sosial Kabupaten Bintan}

Dalam Pemberdayaan Masyarakat Keluarga Miskin Melalui Kelompok Usaha Bersama (KUBE) di Kecamatan Bintan Timur oleh Dinas Sosial Kabupaten Bintan, terdapat beberapa kendala yang menghambat pelaksanaannya.Maka dari itu dibutuhkan upaya yang dilakukan untuk mengatasi kendala tersebut.

Program Pembedayaan Kelompok Usaha Bersama (KUBE) di Kabupaten Bintan sejauh ini memang mengalami bebrapa kendala dan hambatan yang menjadi tantangan suksesnya program ini dalam meningkatkan perekonomian masyarakat demi menciptakan masyarakat yang sejahtera. Namun, Dinas Sosial kabupaten Bintan sebagai instansi terkait sudah berupaya sebaik mungkin dalam melakukan pemberdayaan kepada Kelompok Usaha Bersama (KUBE) yang tergabung dalam program tersebut. Pemerintah sudah berupaya membuat program-program Bazaar yang merupakan salah satu upaya yang dilakukan untuk membantu masyarakat dalam pemasaran produk-produk yang menajdi usaha dari KUBE yang tergabung.Hal itu juga didukung oleh produk dari KUBE sebagian besar adalah makanan, sehingga muda untuk ikut pada bazar-bazar yang dibuat pemerintah.Walaupun upaya melaui bazaar-bazaar tersebut tidak terlalu membantu, karena juga tidak selamanya dan tidak selalu terdapat bazar yang disediakan oleh Pemerintah.

Masyarakat yang tergabung dalam anggota KUBE juga berupaya mencari jalan keluar dan mencari solusi terkait kendala sulitnya pemasran produk ke supermarket karena kendala label halal dan izin dari BPM yang cukup sulit. Ada beberapa KUBE yang kreatif dan memanfaatkan teknologi yang ada untuk 


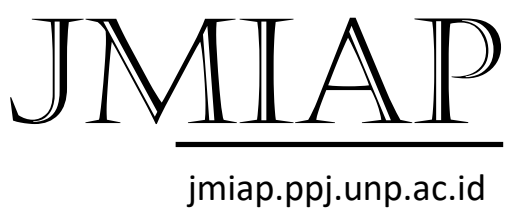

JURNAL ILMU ADMINISTRASI PUBLIK

Email : jianfis.unp@gmail.com

Vol. 2 No. 1 Maret 2019

pemasaran produk, yaitu melakukan penjualan melalui media sosial (Online). Serta melakukan kerja sama dengan warung-warung kecil demi menjaga stabilitas keuangan, karena masyarakat juga mempunyai modal dalam pembuatan produk.

\section{PENUTUP}

\section{Kesimpulan}

Berdasarkan hasil penelitian dan pembahasan yang telah diungkapkan,maka dapat diambil kesimpulan sebagai berikut:

1) Program Pemberdayaan Kelompok Usaha Bersama (KUBE) diberikan kepada masyarakat kurang mampu di Kabupaten Bintan. Bantuan tersebut diberikan dalam bentuk modal usaha, melatih keterampilan masyarakat dengan tujuan meningkatkan perekonomian masyarakat Kabupaten

2) makanan menjadi kesulitan dalam menjalankan usaha.

3) Kendala yang dihadapi dalam pelaksaan program kelompok usaha bersama (KUBE) di Kabupaten Bintan Kecamatan Bintan Timur dapat di katagorikan dalam dua bentuk yaitu Kendala internal dan ekternal. Kendala internal adalah (1) kurangnya Sumber Daya Manusia di Dinas Sosial Kabupaten Bintan, sehingga menyulitkan dalam koordinasi dengan masyarakat yang tergabung dalam kelompok Usaha Bersama (KUBE). Serta kendala internal yang dialami oleh Kelompok usaha yang tergabung dalam program ini, yaitu kendala mecari waktu luang antara anggota kube, dan tidak semua anggota kube mahir dalam menjalankan tugasnya, (2) Kendala Eksternal datang dari kurang baiknya koordinasi antara Dinas Sosial Kabupaten Bintan dengan beberapa Dinas lainnya, yang berakibat pada sulitnya mendapatkan label halal dan
Bintan. Walaupun pelaksaan program Kelompok Usaha Bersama (KUBE) yang dijalankan oleh Dinas Sosial Kabupaten Bintan telah berjalan sesuai prosedur, terutama di Kecamatan Bintan Timur. Namun, program tersebut belum mampu meningkatkan kesejahteraan anggota yang tergabung dalam program KUBE. Hal ini tampak pada beberapa Kelompok Usaha Bersama (KUBE) yang kesulitan dalam pemasaran, dikarenakan tidak diberikannya akses kemudahan dalam pengurusan label halal dan izin dari BPOM, sehingga masyarakat kesulitan memasukan produknya lebih luas, karena itu merupakan persyaratan dari Supermarket dan mini market dan bazar yang dibuat oleh swasta. Hal itu berakibat pada pemasaran produk usaha KUBE yang sebagian besar adalah

perizinan dari BPOM untuk pemasaran produk-produk hasil usaha KUBE ke Supermarket dan Minimarket yang ada.

4) Upaya yang dilakukan untuk mengatasi kendala oleh Dinas Sosial Kabupaten Bintan adalah dengan berkoordinasi dengan Dinas yang memiliki program Bazar untuk memudahkan masyarakat yang tergabung dalam program KUBE ikut serta dalam Bazar tersebut. Serta Upaya lain yang dilakukan oleh KUBE itu sendiri adalah dengan melakukan inovasi pemasaran melalui media sosial (Online), serta bekerja sama dengan warung-warung kecil 
$\prod \sqrt{\| \mathbb{\text { jmiap.ppj.unp.ac.id }}}$

JURNAL ILMU ADMINISTRASI PUBLIK

Email : ¡ianfis.unp@gmail.com

Vol. 2 No. 1 Maret 2019

\section{DAFTAR PUSTAKA}

\section{BUKU}

Haksama, S. P. L. dan S. (2016).

Penerapan Theory O Constraint Pada Kepuasan Kerja Karyawan Rumah Sakit Mata Undaan Surabaya. Jurnal Administrasi Kesehatan Indonesia, 4, 155-162.

Moleong, L. J. (2006). Metode Penelitian Kualitatif. Bandung: PT Remaja Rosdakarya.

Mulyono, E. S. (2017). Kemiskinan Pemberdayaan Masyarakat. Yogyakarta: Ombak.

Nurwati. (2008). Kemiskinan: Model Pengukuran, Permasalahan Dan Alternatif Kebijakan. Jurnal Kependudukan, 10.

Soebianto, T. M. dan P. (2013).

Pemberdayaan Masyarakat Dalam

Perspektif Kebijakan Publik.

Bandung: Alfabeta.

Suyono, H. (2014). Pemberdayaan

Masyarakat di Era Global. Bandung:

Alfabeta.

\section{JURNAL}

Haksama, S. P. L. dan S. (2016). Penerapan Theory O Constraint Pada Kepuasan Kerja Karyawan Rumah Sakit Mata Undaan Surabaya. Jurnal Administrasi Kesehatan Indonesia, 4, 155-162.

Moleong, L. J. (2006). Metode Penelitian Kualitatif. Bandung: PT Remaja Rosdakarya.

Mulyono, E. S. (2017). Kemiskinan Pemberdayaan Masyarakat. Yogyakarta: Ombak.

Nurwati. (2008). Kemiskinan: Model Pengukuran, Permasalahan Dan Alternatif Kebijakan. Jurnal Kependudukan, 10.

Soebianto, T. M. dan P. (2013). Pemberdayaan Masyarakat Dalam Perspektif Kebijakan Publik. Bandung: Alfabeta.

Suyono, H. (2014). Pemberdayaan Masyarakat di Era Global. Bandung: Alfabeta. 